\title{
Minimal critical specification and collective organisational redesign ${ }^{29}$
}

\author{
Johan E. Ravn
}

\begin{abstract}
The purpose of this article is to apply concepts of socio-technical systems thinking (STS), enriched with concepts from more recent organisation theory, to analyse a case of participatory design of core manufacturing processes in a company. The redesign process considered transformation of operational logistics of the installation phase, which is a complex and costly phase. The focus is a test of the concept of minimal critical specification, applied as a principle for work process redesign. In the process under study, managers, supervisors and worker representatives at all levels and functions directly affected took part in the process of redesigning the material flow system and the corresponding control system at the operational level, and the design was put into operation by the company. After a year of operation, the new design was modestly favourably assessed by the organisation. The case shows the possibility and importance of the affected work system's influence in the development, operationalisation and implementation of a new organisation, and the findings demonstrate how manifold relevant participant knowledge may be incorporated into a workable redesign process. The findings cannot be generalised on the basis of this one case, but we will argue that the case serves as a demonstrator project for the model tested.
\end{abstract}

Keywords: minimal critical specification, socio-technical systems, domestication, organisational design, participation, organisational involvement

\footnotetext{
29 The research behind this article was made possible by a grant from the Norwegian Research Council's BIA program, for which I want to express my gratitude.
} 


\section{Introduction}

The case in question is a yard whose core products are offshore topsides (processing facilities) for the global oil and gas industry. Topsides are huge, unique and complex products created in similarly complicated processes. The yard may have three topside projects at different stages in progress at the same time. In the global business, it is not uncommon for a topside project to last four years or more. At the case company, the completion time is compressed to three years. This is achieved by letting the phases of engineering and construction take place partly concurrently, something that of course poses challenges in terms of project management and logistics. In the R\&D project that took place at the yard, the overall objective was to develop and implement a "company-specific production system" (Netland 2013) and use this to improve work quality and organisational performance across the yard's entire set of operations, in all the very different work phases and with all its involved actors (including subcontractors and temporary employees).

The focus of this article is an experimental participatory work process redesign within the so-called installation phase of a topside project. The installation is a very complex, costly and important phase. To put it simply, this is when the physical offshore topside is actually (materially) built. In this phase, a large number of highly skilled workers are engaged, including plumbers, welders, electricians, scaffolders, crane operators and engineers. They all rely on a system that provides them with a steady flow of work tasks, work materials and the necessary tools and equipment. This takes planning, coordination, management, communication, industrial relations (IR), safety management and more, and there is no doubt that it requires high-quality project management and logistics. Based on assessments, reflections and judgements from a whole set of actors, this process (the material logistics of the installation phase) was judged to be in need of improvement. However, views differed widely between roles and departments, e.g., transport, crane operations, warehouse and installation. How could one create a new system that met this diversity of requirements and expectations? How could one envision, design and implement a new material logistics system for the installation phase that was in alignment with the overall production system and at the same time served the core areas of the installation phase in an appropriate manner? How could such a system allow for the local handling of variety without acting contrary to the needs of the overall system? Within this, how could such a redesign be based on a participatory process in a very multidisciplinary field?

Two concepts were judged relevant for the experiment and chosen as central in the theoretical model: the principle of minimal critical specification (MCS) developed in the field of socio-technical theory (Herbst 1974, Cherns 1976, 1987) and the concept of domestication developed in the field of science and technology studies (Silverstone and Hirsch 1992). The MCS principle was chosen because it is a core concept in the socio-technical theory of organisation, and because the initial assessment was that it would address well the challenge at hand: how to go about redesigning a work system characterised by diversity, complexity, distributed power and authority, and expectations about participation. It is important to note that the MCS principle was used not only for the design of the material logistics process but also for the design of the discursive processes through which the relevant actors could analyse, problematise, operationalise, concretise and revise in order to arrive at an agreeable, feasible and operational concept for material logistics at the installation phase. The concept of domestication was chosen in order to understand and handle how an innovation from the outside may be appropriated by its users on the receiving end, since the experiment was likely to include a new material logistics system that would be at least partly understood as an import from outside the system.

The research question was this: how is it feasible to envision, design, anchor and implement a new flow for a complex work process, in a multidisciplinary field, on the basis of a participatory process? 


\section{The yard, its overall production system and the organisational setting}

The yard's model of operation may be characterised as an example of engineering/manufacturing to order. The work is organised into large so-called EPC projects (engineering + procurement + construction). A topside project typically lasts three years, and installation is a core activity of the second half of the project.

Investment in new technology is always important in a manufacturing setting such as the studied case, but acquiring the new technology is never enough on its own. Technology and production systems do not excel unless they are run well through planning, control and management systems, unless the competence is of the right quality, and unless the systems themselves are well aligned with the organisation and its culture. Within manufacturing it has become commonplace to use a corporate business system or company-specific production system (Netland 2013). In general, these are built on a mix of principles from, for instance, Mass Production, Lean Production or Total Quality Management. A well-known example is the Toyota Production System (TPS), which has been a model for many other companies forming their own production system (Ohno 1988). To a large degree, the modern technologies of manufacturing (machines, robots, control systems, communication systems) are available to any organisation with the necessary resources to purchase them. The competitive force lies in the way the technology is put to work in a production system: how the system is designed, organised and managed, and the workforce's ability to perform. The manufacturing model of the studied case, engineering/manufacturing to order, is no exception to this. It is a capital-intensive industry, because of its heavy reliance on sophisticated and expensive technology, but it is also competence-intensive, because of its reliance on competent people from a range of professions.30 The more technology-intensive and competence-intensive the manufacturing systems, the more important the integration and joint optimisation of technology and organisation.

The purpose of project management is to keep projects on track. There are two sides to this: one is the project management system itself, with its recipes, procedures, standards and general regulations for project execution. The other side of project management relates to the day-to-day management within the working practices of a particular project, with its mix of working by the book and improvisation. These two aspects, the system and actual practice, sometimes contradict each other. For instance, sometimes a project's practice needs to work around, or even break, the general project system rules. A core challenge for project management is thus the handling of variety and complexity. The variety (the perturbations) that a system can be exposed to is in principle unlimited. Since only variety can absorb variety, as Ashby noted (1958), a system's internal variety (or diversity) should be customised to prepare for foreseeable as well as unforeseeable contingencies. The overall aim of the yard's production system is to strengthen linkages between generic concepts for technology and production systems and distinctive contextual manufacturing characteristics, thereby offering a methodology for better adaptation/mutual adjustment between corporate recipes and typical local manufacturing strengths/opportunities. The objective is to develop theoretical concepts and practical models for joint optimisation of technologically advanced production systems, control systems and high-performance work organisations.

In a Norwegian context, high-performance work organisations are often based on a participatory logic. Codetermination and participation in company development are important areas of the IR systems at the company level. Regulated both by law and by collective agreements between the social partners, the practices and institutionalisations of collaborative IR ensure the following:

\footnotetext{
${ }^{30}$ Including general managers, construction managers, supervisors, union representatives, planners, and various kinds of engineers, plumbers and electricians.
} 
- Indirect representative co-determination. Trade unions or employee representatives are entitled to be informed, consulted and have co-determination in areas related to major changes in the workplace. They participate in strategic discussions, and they are responsible for monitoring that general employee participation is taking place.

- Direct participation. Employees participate in decision-making that relates directly to their job performance, as well as through their voice in general meetings, department meetings and in the teams (NOU 1985).

Examples of areas where trade unions or representatives are entitled to co-determination are substantial enterprise investments, implementation of new technology, and reorganisation of work, downsizing and restructurings. Codetermination takes place by means of the legislative right for employees to have representatives on the board, and by means of bipartite work councils.

The yard is at the middle of this set of practices and has a strong tradition of seeing union participation in development work as both mandatory and useful. Neither shop stewards nor managers have lost sight of what it is to hold different positions. Although many goals and interests are conflicting, some coincide. This is what makes union-management collaboration a foundation for a very interesting organisational space for exploration of new opportunities. Cooperative and constructive IR are a resource for dealing effectively with disagreements and for developing high levels of trust and communicative skills across all subgroups of an organisation. This organisational proficiency in communication and cooperation across levels, departments, professions, functions, positions and interests has been termed collaborability by Ravn and Øyum (2018). High-performance collaborability gives companies a competitive edge within both operations and innovation work. The organisation gets faster and smarter and develops better learning proficiency; this reduces the costs of coordination and control and eases decision implementation.

\section{Theoretical model}

The research issue was to envision, anchor, design and implement a new flow for a complex work process, in a multidisciplinary field, on the basis of a participatory process. In order to address this, there was a need for a theoretical understanding of the challenges at hand: a theory to explain the processes by which a model or a set of general concepts can be interpreted, may be reinvented, acknowledged, accepted, rooted and made fit for organisational practice. Therefore, for conceiving the organisational process of acquiring a new import, we chose the concept of domestication; for conceiving the organisational design, we chose socio-technical theory and the principle of MCS; and for conceiving the process design, we chose dialogue concepts from the action research tradition.

\section{A. Domestication: the process by which an external object is familiarised into a social system}

New technical solutions, such as a physical machine or an administrative control system, are never "merely" technical. As Orlikowski has argued, "technology results from the ongoing interaction of human choices, actions, social histories, and institutional contexts" (2009:131). Technology or innovation is nothing in itself to the organisation until it has been put to use, and this involves social, cultural and organisational processes. This introduces and strongly supports the domestication approach to understanding technology and innovation. Domestication in a figurative sense is making something taken from the outside world applicable, meaningful and useful to the local world. The concept was taken up in the field of science and technology studies (Silverstone and 
Hirsch 1992) to describe how innovations and new technologies are appropriated by users, be they individuals or organisations.

Domestication theory is a shift away from models taking for granted that the introduction and adoption of technology or innovation is "rational, linear, monocausal and technologically determined" (Berker et al. 2006:1). Domestication theory holds that adoption/appropriation is always an interactive process, as opposed to a more oneway view (determinism) where an import is simply introduced and therefore forces the local organisation to adapt to it. Domestication is a process of reconfiguring and reshaping a culture and organisation, and it highlights both the practical/material and the symbolic/cultural sides of the domesticated object. A particularly interesting aspect of domestication theory is that it highlights the role of local users in making symbolic and practical sense of an import from the outside within a local setting. A new system of material logistics, for example, has to be "housetrained", that is, integrated into the structures, routines and values of the place where it is being introduced (Berker 2006), and this is an active reconstruction process within the host system. In the case under study, domestication is the process by which the generic recipe for the topside yard's material logistics is paraphrased and made meaningful and applicable to the local workstations. The challenge is to construct alignments between the concept and the local particulars in terms of technology, competence, organisation and culture. This process entails cognitive, symbolic and practical aspects (Sørensen 2006), as follows:

- cognitively, how do workers and managers get to learn, understand and know the new concept, and how do they learn from one another?

- symbolically, what kind of meanings do they ascribe to it?

- practically, how do the involved actors put the concept into practice during their workday, as individuals, as teams and as a whole?

Understood as domestication, the new system of material logistics will be rescripted when organisation member users read, interpret and act. In this new, local rescript, the system is integrated with the practices, meanings, people and other artefacts at hand (Sørensen 2006).

\section{B: Minimal critical specification: a structure for maximising the system's own role in its design}

"There is no social that is not also material, and no material that is not also social" (Orlikowski 2007:1437). Sociotechnical theory focuses on the interface of the people and the technology at work. In the decades after WW2, work life went through major changes, and socio-technical systems theory (STS) was developed to address the challenges. STS was a theory of the design and operations of organisations formulated as an alternative to the bureaucratic and Taylorist approaches that advanced universal principles and regarded organisations as machines and, consequently, workers as machine parts. For STS, designing appropriate organisations was based on a comprehensive analysis, with special emphasis on the organisation's environments, the technology in use and, not least, the quality of jobs. Socio-technical theory focuses on the interface of the people and the technology in the work, and it allows for and invites workers' involvement in the organisation of the working processes (Cherns 1976, Trist and Murray 1993).

A core concept from classic STS is the work team (a semi-autonomous team). The concept of work groups or teams first came into organisation theory through the studies of the Western Electric factories by Mayo and others (Mayo 1949),31 but the concept of team-based organisation design arrived with early STS (Trist and Bamforth 1951) and

31 The Hawthorne study (Mayo1949), although its results and conclusions have been contested by many later authors, nevertheless formulated the idea of social groups or teams as part of the (informal) organisational structure, and the Hawthorne study is presented in most basic textbooks of organisation theory. 
is widely used today. Other important concepts in early STS were redundancy of function, e.g., in high-performance work systems, as an alternative to the redundancy of parts (cf. scientific management), the learning organisation, 32 joint optimisation (of the technical and the social systems of the organisation) and psychological job requirements (Emery and Thorsrud 1976). Several of these concepts have survived and have become key concepts within other forms of production organisation and management theory (Klemsdal et al. 2017).

Minimal critical specification. Related to the concept of team is the concept of responsible autonomy. A system with responsible autonomy is characterised by the following traits:

- Members of the system share responsibility for a definable total task with measurable outcomes in terms of quantity and quality.

- There are interdependencies between the members of the system.

- There is some system autonomy in how to organise tasks among members (Trist et al. 2013[1963]:21).

It is in the third point, autonomy in how to organise tasks, that Herbst's concept of MCS comes in. Autonomy, or organisational slack, can be established by "deliberately avoiding too much detailed information and specifications of the new" (Amble 2017). STS theory holds that organisational slack is a prerequisite for learning and development processes among employees. MCS is a key design principle when it comes to designing planned change. The point is to make the fewest possible critical specifications in advance of the implementation of a new design "in order to leave it to the workers to complete the designs as they enact them in their daily work, through experimentation, improvisation, and learning processes" (Klemsdal et al. 2017). In the words of Herbst:

"The principle of minimal critical specification design can be stated as that of identifying the minimal set of conditions required to create viable self-maintaining and self-adjusting production units. An optimal solution is obtained if the unit requires no external supervision and control of its internal functioning and no internal staff concerned with supervision, control or work coordination. The management function should primarily be supportive and concerned with mediating the relationship of the unit to its environment" (Herbst 1993:296).

Minimal is not the same as non-existent: a specification of the critically important elements must be in place, whereas the rest is left to the local users. According to Cherns (1976), the principle may be formulated both positively and negatively: one has to identify what is essential and inevitable, but no more should be specified than is essential and inevitable. Lars Klemsdal (2013, quoted in Amble 2017) connected MCS with the concepts of sensemaking (Weick 2001) in a research project. In good examples, employee dialogues about problematic situations at work became constructive cases of learning that made sense. In the solutions the employees arrived at, sensemaking and MCS came together to support learning within a work organisation.

MCS runs counter to conventional practices of project planning, where one often seeks to specify as much as possible in order to maintain control. To Herbst, the MCS way of specifying work tasks is an alternative to the detailed specification of the typical work hierarchies; that is, a manner of allowing for local organisational space to test out new practices and learning. Herbst promotes this as a hallmark of learning organisations, namely that MCS is both necessary and sufficient to enable learning (Amble 2017). On the basis of their own experience, when faced with MCS, workers are given space to "discuss, learn, and have autonomy to try out what they consider to work well" (Amble 2017:95).

MCS concerns work or organisation design: it is a principle for how a work process, for example, should be designed. In this case, we wanted to utilise the concept for the design of the process of designing, and not just the

32 The concept was coined by Herbst before being taken up by Argyris and Schön (1978) and Senge (1990). 
outcome of the design (the resulting work process). To understand the challenges of each specific workstation, as well as how to address these challenges, there is a need to understand the particulars of the specific workplaces. Another reason why it is necessary to include these particulars is that this requires the participants to "reveal their assumptions for challenge" (Cherns 1987:156). When this is done, some assumptions may hold and will have a role to play in the design, whereas others may be falsified. The general design concepts are useful as a starting point, but when it comes to which concepts to apply (their specific contents as well as the relationship between them), this has to be settled by each workstation in its own way.

\section{Action research concepts of dialogues and change}

For all its potential usefulness, MCS does not have much to say about how to facilitate a design process. As discussed above, there is a tradition of worker participation and autonomy at the yard. Employees are expected to be responsible, reflective and engaged in developing their own work. Likewise, trade unions, shop stewards and employees expect to be listened to and taken into account. In order to put a principle such as MCS into practice, there is a need for process facilitation.

It was not merely to let voices be heard that we wanted to draw participation and diversity into the design phase. Just as important was ensuring the quality of the solution. As Elden put it:

"the outside expert has general theoretical knowledge as well as knowledge in organizing change (process knowledge). Workers have concrete knowledge about their own workplace, especially how things 'hang together' in that workplace" (1983:22).

A similar claim has been made by others: that some sorts of local organisational expertise are not tapped into unless the process is sufficiently participatory.33 Elden, however, goes on to make a slightly different point:

"different theories lead to different actions, and workers seem to have at least potentially high changerelevant knowledge but low change-relevant authority while management has low knowledge but high power" (1983:33).

This is not just pointing to local knowledge about "how things are"; it also implies that in order to make changes come about, there is something "change-relevant" in the local knowledge. On the other hand, the management side to this is also important, because it contributes the necessary power. Greenwood makes a similar argument but broadens it. There are of course many interests and parties in an organisation such as the one under study. These interests differ, and they may fluctuate and change. The handling of the organisational interest is thus a handling of diversity. As Greenwood puts it:

"Managers and workers alike tend to treat each other's visions and experiences as defective or even duplicitous. The realization that there is room, and perhaps even an organizational requirement, for a diversity of views and experiences of an organization is an essential step in the direction of reflective practice and organizational learning" (Greenwood 1991:89).

Participation and diversity are therefore called for. However, they do not come about by mere invitation. It takes arena structuring and facilitation of communicative interaction, a process through which the actors aim at reaching a shared understanding. As Habermas argued:

33 This is, of course, an argument that is valued within action research. See also the section on Methodological approach. 
"in communicative action participants are not primarily oriented to their own individual successes; they pursue their individual goals under the condition that they can harmonize their plans of action on the basis of common situation definitions" (1984:284-5).

The communicative theory of Habermas is a foundation for many action research models of participation. We will not go into them here. Suffice to say that there is solid tradition within action research of placing great emphasis on the facilitation of free dialogue between the participants in any reflection and change effort.34

Nevertheless, free dialogue is not all that is required. Even a situation of full inclusion would not guarantee that the process does justice to the knowledge of all participants, because we cannot fit all of our experiences and thinking into an argumentation process. The representation of a practice within a communication process is limited to the part of the practice that we can express, but we know more than we can express in words. As Polanyi put it in his discussion of so-called tacit knowledge, "We can know more than we can tell" (1983:4). The main traits of tacit knowledge are that it is difficult to communicate and that it is embedded in the person or in the organisation, but the concept of embeddedness may help us out. In our approach, we sought to embed the discourse in shared situations of practice. Having been through shared experiences, spoken words can rely on a rich and relevant context and reservoirs of unexplained knowledge about the situation on which we dwelt. This is what we call embedded knowing. Shared contexts enrich the shared conversations about practice. Donald A. Schön's concepts of reflectionon-action or conversation with the situation capture what this is about (1983). Building on the field situation that the actors shared, we were able to keep a conversation going in which the concepts and words were embedded, and therefore more meaningful than otherwise. The participants took part in a joint praxis, aiming at concrete problemsolving, and in this praxis, new shared understandings are generated jointly, within and also beyond the explicit concepts. The process by which this knowledge is generated is one in which the contributors are diverse. It is only because they share a practical activity that they can do this. The knowledge generated transcends disciplinary borders.

\section{Methodological approach}

In such a multidisciplinary field, how can work process redesign be built on a participatory process? This question was dealt with using an action research approach, focusing on interactivity between researchers and participants through all the stages (Holtgrewe et al. 2015), cogenerative learning (Elden and Levin 1991), pragmatic problemsolving and increased ability of those involved to be in control of their situation (Greenwood and Levin 2007).

The empirical basis for this article is a so-called interactive research design in which researchers and groups of partners worked together to develop new knowledge. The concept of interactive research emphasises a shared process between field and research in most or all phases of the research (Holtgrewe et al. 2015). The cogenerative learning perspective views all participants as capable of and involved in creating new solutions (Elden and Levin 1991) and aims to "open horizons of discussion, to create spaces for collective reflection in which new descriptions and analyses of important situations may be developed" (Greenwood and Levin 2007:72).

In this case, this meant that company insiders took part in previous phases of research (studies, fact finding, reflections and conceptualisations) and in the case itself. From a substantial amount of previous work over several years, including site visits, interviews, observations, meetings, workshond analysis of corporate figures/data and industry statistics, the researchers knew the company well, and many of the participants knew the researchers. This

34 See, e.g., Gustavsen 1992, Greenwood and Levin 2007, Forester 1999, Argyris et al. 1985, Kemmis 2008. 


\section{E UROPEAN JOURNAL OF W ORKPLACE INNOVATION}

base strengthened the potential for open and honest communication. Based on this, and on a phase of fact finding and preliminary analysis conducted jointly by the external researchers and company insiders, a draft of a concept for a new material logistics system for the installation phase was developed. This concept was more ideal and in principle than detailed or practical. In order to make it into company reality, two challenges had to be met:

- The core work groups of the installation phase had to understand, accept and adopt a new logic for it to become organisational reality.

- The new shared logic had to be developed into a work process design sufficiently concrete, operational, practical, detailed and fit for the core areas of the installation phase without losing its alignment with the logic of the overall company production system.

There is no valid claim for generalisability about the findings concerning work design processes. The objective was of an exploratory kind: to see, contribute to and interpret the processes of domestication of a logistics design through MCS. We do, however, think that the case works as a demonstrator project. As Herbst argued, a demonstration experiment has two purposes: to show that something can be implemented in reality and to provide data that can be summarised in more general principles (1993:409).

\section{Accounting for the change and development process}

The logistics of the installation phase may be set out in the following manner:

- A supervisor at the installation site logs into the company ERP35 systems and assumes responsibility for a defined work task for a work team.

- Based on the work task, a material order is placed into the system, and this is sent to the warehouse.

- The warehouse gathers the materials, partly bulk material gathered from the shelves inside the warehouse, and partly unique ("tagged") custom-made parts stored elsewhere.

- The warehouse calls for transport.

- Transport picks up the materials and moves them over to a pick-up point somewhere near the installation site.

- Transport calls for crane service.

- A crane operator lifts the material to a pick-up point ("platform") for the work crew at the installation.

- The material is assembled into the installation, and the assigned work team completes the work task and reports it as completed.

- The supervisor assumes responsibility for a new work task on behalf of the work team.

The research team conducted a thorough analysis of the performance of the logistics of the installation. This analysis was based on a multitude of methods, including observation, analysis of previous reports and other secondary data, meetings, interviews, measurements, technical calculations and benchmarking. A number of problematic issues were identified, and the following challenges were presented at a plenary session at the start of the design workshop (Table 1).

35 ERP systems: Enterprise resource planning systems; a set of integrated software applications used to collect, store, manage, and interpret data to exercise control. 
Table 1. Challenges at the start of the design workshop.

\begin{tabular}{|l|ll|}
\hline Occupied space & $\begin{array}{l}\text { No available space at terminal/crane because the current day's informal buffer storages } \\
\text { occupy all the space available } \\
\text { No space to manoeuvre within the installation zone because of all the parts that are stored } \\
\text { everywhere }\end{array}$ \\
\hline Inventory & $\begin{array}{l}\text { Lots of formal and informal inventories all the way through the work process between } \\
\text { warehouse and the final installation zone }\end{array}$ \\
\hline Missing parts & $\bullet \begin{array}{l}\text { Lots of time spent looking for particular parts stored under the platform and the like, because } \\
\text { parts are placed in unstructured piles everywhere }\end{array}$ \\
\hline Imprecise ordering, & $\begin{array}{l}\text { - } \\
\text { long response time }\end{array}$ & $\begin{array}{l}\text { Warehouse requiring } 48 \text { hours to respond } \\
\text { Parts often ordered many weeks in advance }\end{array}$ \\
\hline Imprecise delivery (warehouse - transport - crane)
\end{tabular}

The initial preparatory analysis of the installation work process above was the starting point for the design workshop. Based on analysis of the empirical findings and scrutinised in the light of the company's general makeover plans, a new concept for the material logistics was developed. Our aim was a concept robust enough to withstand the various critical voices that we might meet from the various work areas within installation. According to van Amelsvoort and van Hootegem, "robust" means that interferences in core work process are minimised, and that the design of organisations should include all stakeholder perspectives (2017:291). To arrive at a conceptual model (such as a logic of material logistics) that is understood and acknowledged by the actors involved, the model must solve people's problems and empower them to increase control over their own situations. This process can be achieved only with participation (Levin 1993).

The process thinking we aimed for was a methodology that would help establish a shared situational understanding between participants. There was a need to identify all the key interests and viewpoints to make sure they were included in the further process. The best guarantee for the success of an organisation design process is to fetch "the whole system into the room" (Weisbord 1992) The workshop design was created by researchers and key company stakeholders, but the design of the new logistics system was drafted as a co-creation with several of the operationslevel stakeholders.

The gains targeted by the concept for a new material logistics were better efficiency, better flow, lower costs, less waiting and, hence, less frustration. Based on the analysis of the prevailing logistics, a set of characteristics of the new logistics were presented to the participants at the design workshop (Table 2). 
Table 2. Target gains for the new concept of material logistics.

\begin{tabular}{|c|c|}
\hline $\begin{array}{l}\text { Area of work } \\
\text { process }\end{array}$ & Target gain \\
\hline $\begin{array}{l}\text { Construction } \\
\text { management }\end{array}$ & $\begin{array}{l}\text { Better efficiency } \\
\text { Better flow } \\
\text { Lower costs }\end{array}$ \\
\hline Warehouse & $\begin{array}{l}\text { "Kitting": all work material for a designated work task packed as kits arriving at the installation site at } \\
\text { the same time } \\
\text { Delivery time (from warehouse) reduced from maximum } 48 \text { hours to four hours }\end{array}$ \\
\hline Planning & Uncover deviations earlier and/or provide a longer and more precise planning horizon \\
\hline Transport & $\begin{array}{l}\text { All material transport carried out according to fixed route/timetables, with fixed platforms } \\
\text { Shorter response time } \rightarrow \text { more accurate ordering } \rightarrow \text { more accurate transport }\end{array}$ \\
\hline Crane & Better space at the terminal/crane because of the removal of "buffer storage" \\
\hline Installation & $\begin{array}{l}\text { Better space inside the installation zone because parts do not arrive before they are needed and do not } \\
\text { stack up } \\
\text { Higher precision when goods arrive } \rightarrow \text { less waiting } \\
\text { Less searching for parts under the platform and the like } \\
\text { Less walking to get parts from the warehouse } \rightarrow \text { more time spent in the "value field" }\end{array}$ \\
\hline Overall & $\begin{array}{l}\text { Smaller buffer inventory } \rightarrow \text { no interim storage between warehouse and installation zone } \\
\text { Fewer errors and less waste (fewer customised, expensive parts disappear) }\end{array}$ \\
\hline
\end{tabular}

The workshop was organised as a model of the material logistics process itself. All involved groups participated: 25 people, including the researchers. The conference process moved from an overall presentation of fact finding/analysis to a general idea for a new concept for yard logistics, and on to local-level concretisation, operationalisation and (in some instances) a reframing of the overall model. The following critical success factors were discussed and anchored at the workshop:

- each of the individual departments/work areas (e.g., transport or warehouse) should take responsibility for developing and improving their own parts of the total work process

- each of the individual departments/work areas should seek opportunities to enable the other departments/work areas to improve.

A critical phase of the workshop was the so-called "world café" session (Klev and Levin 2016), the design of which is shown in Figure 1. 


\section{E UROPEAN JOURNAL OF W ORKPLACE INNOVATION}

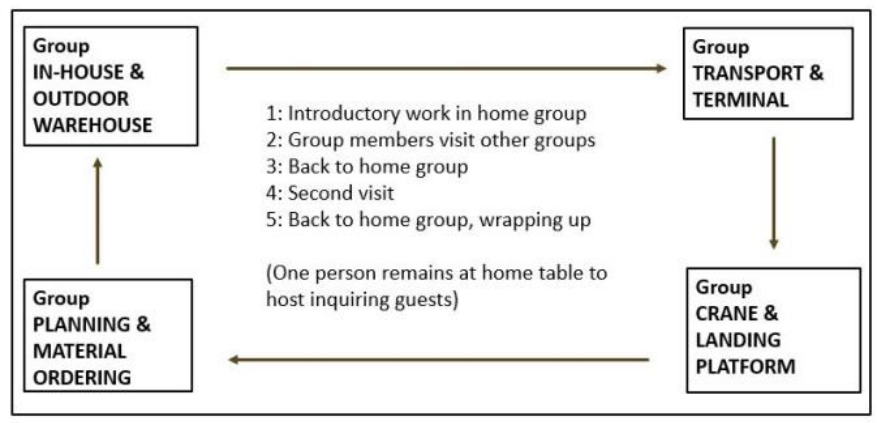

Figure 1. The world café workshop design.

In this phase, the workshop was organised into four groups representing the four main departments/work areas as sequences of the material logistics process. They gave their reactions to the overall material logistics model, identifying errors and challenges likely to appear as the model is concretised and operationalised, and remaking it as their own model, fit for their area, while repeatedly aligning their solutions with the work stages prior to their own (those of their "suppliers") and following their own (those of their "customers").

By the end of the design workshop, the participants had identified a set of challenges, bottlenecks and critical points, but also ways to deal with them. In most cases, they had the necessary resources among themselves, but for some issues, they would have to rely on others (e.g., people at the ICT department and, of course, the wider supply chain of which they were only a tiny part). They had also identified tasks, milestones and people responsible for most of the actions identified and had drawn up an agreement for implementing the new design. This was all put together into an implementation plan.

Almost a year (10 to 11 months) after the design workshop, a review workshop was held. Sixteen persons participated, including union representatives, representatives of each phase of the process, supervisors, overall construction management and researchers. Prior to the workshop, the overall construction management had interviewed various people in the work processes in or related to yard logistics. This feedback was shared and discussed, and the reflections of the participants were added to the picture. The overall assessment of the new design for the work process of yard logistics was positive. The core objective, increased productivity, had not been met sufficiently, at least not according to the metrics used, but several participants held that it was too early to focus on this. Productivity is a lag indicator, and most core lead indicators projected that the new work process would become more productive. Key findings from the workshop are summarised in Table 3. 
Table 3. Key performances of the revised material logistics model.

\begin{tabular}{|l|l|}
\hline Area of work process & Key findings \\
\hline Construction management & $\begin{array}{l}\text { Zero problems reported from system to construction management } \\
\text { Overall outlook: more order and tidiness, fewer superfluous aspects } \\
\text { A higher degree of multidisciplinary thinking from all involved }\end{array}$ \\
\hline Warehouse & $\begin{array}{l}\text { Kitting of work packages completed, with few delays and few problems } \\
\text { Material orders handled within two hours (on average) } \\
\text { New work process assessed as more manageable than expected }\end{array}$ \\
\hline ICT system & $\begin{array}{l}\text { Kitting of work packages completed } \\
\text { ICT system could be improved to serve the process better }\end{array}$ \\
\hline Transport & $\begin{array}{l}\text { Better flow and smoothness in transportation } \\
\text { Less effort to search out where in the system the load carriers are located } \\
\text { Transport's low expectations about the feasibility of the new model proved unfounded }\end{array}$ \\
\hline Crane & $\begin{array}{l}\text { Fixed terminals had worked well without creating buffer inventories } \\
\text { Crane was sometimes a bottleneck }\end{array}$ \\
\hline Installation & $\begin{array}{l}\text { Less buffer inventory and more space to operate in } \\
\text { Warehouse perceived as attentive and helpful }\end{array}$ \\
\hline Overall & $\begin{array}{l}\text { More work processes should be designed like this } \\
\text { Stronger planning required, particularly with regard to vacation periods and high-intensity } \\
\text { phases } \\
\text { A focus on training also required }\end{array}$ \\
\hline
\end{tabular}

\section{Findings}

We will first summarise the findings according to what we take to be three core types of results: value added (what kinds of practical results have been produced in terms of how participants improved their ways of working?), organisational involvement (to what degree and how have the processes developed the capacity for inclusion and participation and, hence, organisational performance?) and knowledge production (what new understandings have been developed about participatory design?). After that, we will discuss the merits of the theoretical approach that guided the research.

Value added. Judging from the assessments made by the organisational actors themselves, their new concept for material logistics was a success, albeit a modest one. After 11 months, it had not met their productivity objectives; it is not for us to speculate about whether this is likely to change with time. On the other hand, all of the departments or disciplines involved reported positively about their new design in terms of improved flow, increased smoothness, less stress and more control over their own areas. A system such as material logistics is a complete set of relations between various elements that together perform a certain function. Such relations are always social as well as technical, hence the aptness of a socio-technical perspective. The yard logistics case demonstrates the possibility and importance of the affected work system's influence in the development, operationalisation and implementation of a new organisation.

Organisational involvement. "Long-term change in any organisation cannot be achieved on the basis of remote expert diagnosis by consultants and recommendations endorsed only by higher management. Participation at all 
levels is essential" (Jackson 2003:106). The concept for participatory work process redesign developed in this research project describes a new mode of thinking and operating and offers guidelines for how go about participatory design in complex production flows. A new level of performance was sought and achieved through a participatory and diverse interplay between skills (individual as well as collective), knowledge, technology (tools, equipment etc.) and practice. The new cogenerated concept was based on a balanced consideration of a whole set of performance areas. It developed into a concept with added detail and concretisation to make it work better without obstructing the overall company-specific manufacturing concept. This was in line with the guiding principles of local ownership, participation and MCS.

Knowledge production. At the start of the design workshop, as seen from the workstations involved in installation, the new model for material logistics was an import from the external environment. It was very general, and it was clearly not theirs. Nevertheless, this was changed through the reflections and communicative interactions of the workshop, where the participants virtually role-played the material logistics taking place across their workstations. From the pre-studies, it was well known that there were conflicting views across the functions, e.g., between installation and warehouse or between transport and overall planning. These could not be overlooked, and therefore ample space was given in the process design for such conflicts; in fact, they could be immediately addressed, since all parties were present. All kinds of practical issues concerning the concrete operations at the interfaces did not have to be put entirely into words, because both parties to the interface were present. Through this process, the conceptualisation of the new logistics concept was cognitively, practically and culturally domesticated by the actors in and around material installation: the new concept became known and understood, and was reframed through their own concretisations. The workshop also offered the participants a practical rehearsal of the new concept. It is our impression that by means of a concept-defined MCS, put into a carefully facilitated "cogenerated process" and situated in an arena mimicking the actual interfaces, the work system gradually domesticated the concept of material logistics to make it work for them.

Domesticating an imported design by remaking and concretising it. The new design for material logistics was developed from the outside but put to use by the actors on the inside. This is a case of domesticating an artefact. Judged by the local actors themselves, and assessed in the perspectives of value added, knowledge production and organisational involvement, the process was successful overall. As Sørensen put it, domestication is about enactment (2006). This enactment takes place as a kind of taming: the new script will have to be rescripted. This takes place as the involved actors read, understand, ascribe meaning, interpret, reinterpret and act. The yard actors' domestication of a new design for material logistics may usefully be understood as a movement of a preliminary and general idea tamed and enacted "into and within existing socio-technical arrangements" (Sørensen 2006:47). This taming did not end at the workshop, but it started there. If we trust the judgement of the local participants a year later, they have coped well.

\section{Conclusion}

To strive and prosper in the global competition of the future, industries like the yard need to remain willing to make changes in their ways of working, and this requires the organisational ability to conceive and implement such changes. A change process in an organisation as complex as the yard, even a process restricted to only a section of it, implies challenges. It cannot be split up and treated as a set of separate elements, because everything is interrelated. Neither can it be dealt with in the classical manner of someone planning and deciding but leaving the implementation to other people, because it takes the knowledge and participation of many to make the change come about. Faced with complexity, uncertainty and ambiguity, the organisation must tap into its total base of knowledge, practice and diversity, and this requires the ability to facilitate collective action. Managers, experts and other leading figures certainly play important roles, but they are not sufficient. To change an organisation, it is not enough to change management strategies, roles or knowledge. The challenge of arena and process structuring in a manufacturing setting is to establish a development process with vested interests, not just across departments but 
also across disciplinary-based professional identities and across traditional hierarchies. It is a matter of pursuing productive communication across disciplinary borders without nullifying differences.

In the case under study, the core mechanism in the practical reconceptualisation and enactment of a new theoretical concept was the participants' professional experience and the deliberative space allowed for and carefully facilitated: a collective "conversation with the materials of a situation" (Schön 1983:78). The concept of minimal specification offered a design principle for this. The concept of domestication offered a theoretical model to understand what is at stake when something new is to be enacted in an organisation. Action research offered a communicative and processual understanding and guidance that increased the organisation's ability to go about domestication in a deliberate and collective manner.

\section{References}

Amble N. (2017). "A learning organization in practice: service development in care work." Nordic Journal of Working Life Studies 7.S2 2017 Pp 91-106.

Argyris C., Putnam R., \& Smith D.M. (1985). Action Science. San Francisco, Jossey-Bass.

Argyris C. \& Schön D.A. (1978). Organizational Learning: A Theory of Action Perspective. Reading, MA, Addison-Wesley.

Ashby W.R. (1958). An Introduction to Cybernetics. London, Chapman \& Hall.

Berker T., Hartmann M., \& Punie Y. (Eds.) (2006). Domestication of Media and Technology. Maidenhead, Open University Press.

Cherns A. (1976). “Principles of sociotechnical design.” Human Relations 29.81976 Pp 783-792.

Cherns A. (1987). "Principles of sociotechnical design revisited.” Human Relations 40.3 1987 Pp 153-161.

Elden J. (1983). "Democratization and participative research in developing local theory." Journal of Occupational Behaviour 4.1 1983 Pp 21-34.

Elden M., \& Levin M. (1991). “Cogenerative learning: bringing participation into action research.” Pp 127-142 in W.F. Whyte (Ed.), Participatory Action Research. Newbury Park, CA, SAGE Publications.

Emery F. and Thorsrud E. (1976). Democracy at Work. Leiden, Martinus Nijhoff.

Forester J. (1999). The Deliberate Practitioner. Cambridge, MA, MIT Press.

Greenwood D.J. (1991). "Collective reflective practice through participatory action research: a case study from the Fagor cooperatives of Mondragón.” Pp 84-107 in D.A. Schön (Ed.), The Reflective Turn: Case Studies in and on Educational Practice. New York, Teachers College Press.

Greenwood D.J., \& Levin M. (2007). Introduction to Action Research. Thousand Oaks, CA, SAGE Publications. 


\section{E UROPEAN JOURNAL OF W ORK P L A C E IN N O V A T I ON}

Gustavsen B. (1992). Dialogue and Development. Assen, van Gorcum.

Habermas J. (1984). The Theory of Communicative Action. Vol. 1. Reason and the Rationalization of Society. Boston, MA, Beacon Press.

Herbst P.G. (1974). Socio-Technical Design: Strategies in Multidisciplinary Research. London, Tavistock Publications.

Herbst P.G. (1976). Alternatives to Hierarchies. Leiden, Martinus Nijhoff.

Herbst P.G. (1993). "A learning organization in practice, M/S Balao". Pp 409-416 in E. Trist \& H. Murray (Eds.), The Social Engagement of Social Science: A Tavistock Anthology. Volume II The Socio-Technical Perspective. Philadelphia, PA, University of Pennsylvania Press.

Holtgrewe U., Markova E., \& Ravn J.E. (2015). "A hard job is good to find: comparability, contextuality and stakeholder involvement in European job quality research". In U. Holtgrewe, V. Kirov \& M. Ramioul (Eds.) Hard Work in New Jobs: The Quality of Work and Life in European Growth Sectors. London, Palgrave Macmillan, Pp 11-32

Kemmis S. (2008). "Critical theory and participatory action research". In P. Reason and H. Bradbury (Eds.), The SAGE Handbook of action research. London, Sage Publications Pp 121-138.

Klemsdal L., Ravn J.E., Amble N., \& Finne H. (2017). "The organization theories of the industrial democracy experiments meet contemporary organizational realities." Nordic Journal of Working Life Studies 7.S2 2017 Pp 115 http://dx.doi.org/10.18291/njwls.v7iS2.96687

Klev R., \& Levin M. (2016). Participative Transformation: Learning and Development in Practising Change. London, Routledge.

Levin M. (1993). "Technology transfer as a learning and developmental process." Technovation 13.81993 Pp $497-$ 518.

Mayo E. (1949). "Hawthorne and the Western Electric Company." Public Administration: Concepts and Cases. 1949 Pp 149-158

Netland T.H. (2013). "Company-specific production systems: managing production improvements in global firms." Doctoral thesis. Department of Industrial Economics and Technology Management, NTNU, Trondheim.

NOU (1985). NOU 1985:1: Videreutvikling av bedriftsdemokratiet (Continuing Development of the Industrial Democracy). Oslo, Norwegian University Press.

Ohno T. (1988). Toyota Production System: Beyond Large-Scale Production. Portland, OR, Productivity Press.

Orlikowski W. J. (2007). "Sociomaterial Practices: Exploring Technology at Work." Organization Studies 28(9) 2007 Pp1435-1448.

Orlikowski W.J. (2009). "The sociomateriality of organisational life: considering technology in management research." Cambridge Journal of Economics 34.1 2009 Pp 125-141. 


\section{E UROPEAN JOURNAL OF W ORKPLACE INNOVATION}

Polanyi M. (1983). The Tacit Dimension (Reprint). Gloucester, MA, Peter Smith.

Ravn J.E., \& Øyum L. (2018). "Towards 'multi-collar' unionism: cases of trespassing professionals in Norwegian industrial relations." Economic and Industrial Democracy 2018 http://dx.doi.org/10.1177/0143831X17743794

Schön D.A. (1983). The Reflective Practitioner: How Professionals Think in Action. New York, Basic Books.

Senge P. M. (1990). The Fifth Discipline. The Art \& Practice of The Learning Organization. New York, Currency Doubleday.

Silverstone R., \& Hirsch E. (Eds.) (1992). Consuming Technologies: Media and Information in Domestic Spaces. London/New York, Routledge.

Sørensen K. H. (2006). "Domestication: the enactment of technology". Pp 40-71 in T. Berker et al. (Eds.), Domestication of Media and Technology. Maidenhead, Open University Press.

Trist E. L. \& K. W. Bamforth (1951). "Some Social and Psychological Consequences of the Longwall Method of Coal Getting." Human Relations 4.11951 Pp 3-38.

Trist E.L., Higgins G.W., Murray H., \& Pollock A.B. (2013 [1963]). Organizational Choice: Capabilities of Groups at the Coal Face under Changing Technologies. The Loss, Re-Discovery and Transformation of a Work Tradition. London, Routledge.

Trist E., \& Murray H. (Eds.) (1993). The Social Engagement of Social Science: A Tavistock Anthology. Volume II The Socio-Technical Perspective. Philadelphia, PA: University of Pennsylvania Press.

Van Amelsvoort P., \& van Hootegem G. (2017). "Towards a total workplace innovation concept based on sociotechnical systems design.” Pp 281-299 in P.R.A. Oeij, D. Rus, \& F.D. Pot (Eds.), Workplace Innovation. Springer.

Weisbord M.R. (Ed). (1992). Discovering Common Ground. San Francisco, CA, Berrett-Koehler Publishers.

Weick K.E. (2001). Making Sense of the Organization. Oxford, Blackwell.

\section{About the author:}

Johan Elvemo Ravn, PhD, is professor of Leadership and organization at Nord University, Norway and senior research scientist at the SINTEF foundation. Research interests include organization, leadership, collaborative industrial relations, action research and sociotechnical systems theory. He has published and been guest editor in several journals. 